\title{
Revalidation of Saccocoelioides bacilliformis (Digenea, Haploporidae) parasitizing species of Astyanax (Characiformes, Characidae) from southern Brazil
}

\author{
Moisés Gallas (1) \& Laura R. P. Utz
}

\begin{abstract}
Laboratório de Ecologia Aquática, Escola de Ciências da Saúde e da Vida, Pontifícia Universidade Católica do Rio Grande do Sul, Porto Alegre, $90619-900$, Rio Grande do Sul, Brazil. (mgallas88@gmail.com, laura.utz@pucrs.br)
\end{abstract}

Received 15 August 2019

Accepted 22 October 2019

Published 2 December 2019

DOI 10.1590/1678-4766e2019039

ABSTRACT. In Argentina, Saccocoelioides bacilliformis Szidat, 1973 was described from specimens collected probably in Astyanax bimaculatus (Linnaeus, 1758), but latter it was synonymyzed with Saccocoelioides octavus Szidat, 1970. During the examination of digenetic trematodes collected in different species of Astyanax Baird \& Girard, 1854 from southern Brazil, we found specimens identified as Saccocoelioides. A detailed comparison of the morphology of the two species revealed that they should be considered valid, thus this study proposes the revalidation of $S$. bacilliformis. The traits that allowed the revalidation were: body shape, position of the caecal bifurcation, and the extension of the uterus and vitellarium. Parameters of infections are provided for the first time in addition to records of new hosts and new locality.

KEYWORDS. Chalcinotrematinae, haploporid, characid, redescription, Taxonomy.

RESUMO. Revalidação de Saccocoelioides bacilliformis (Digenea, Haploporidae) parasitando espécies de Astyanax (Characiformes, Characidae) do sul do Brasil. Na Argentina, Saccocoelioides bacilliformis Szidat, 1973 foi descrita a partir de espécimes coletados provavelmente de Astyanax bimaculatus (Linnaeus, 1758), mas posteriormente foi sinonimizada com Saccocoelioides octavus Szidat, 1970. Durante o exame de trematódeos digenéticos coletados de diferentes espécies de Astyanax Baird \& Girard, 1854 no sul do Brasil, foram encontrados espécimes identificados como Saccocoelioides. Uma comparação detalhada da morfologia das duas espécies revelou que elas devem ser consideradas válidas, portanto este estudo propõe a revalidação de S. bacilliformis. Os caracteres morfológicos que permitiram a revalidação foram: formato do corpo, posição da bifurcação cecal e a extensão do útero e vitelário. Os parâmetros das infecções são fornecidos pela primeira vez, bem como o registro de novos hospedeiros e de uma nova localidade.

PALAVRAS-CHAVE. Chalcinotrematinae, haploporídeo, caracídeo, redescrição, Taxonomia.

The genus Saccocoelioides Szidat, 1954 was proposed to accommodate seven species of digenetic trematodes which presented vitellarium formed by rounded and large follicles, distributed in lateral fields and extend from the ventral sucker region to the middle posterior region of the body (SzIDAT, 1954). Latter, OvERSTREET \& CURRAN (2005) considered that species of Saccocoelioides present a combination of the following traits: intestinal caeca small sac-like or moderately long, never ending close to the end of the body; eyespot concentrated or diffuse and miracidium containing eyespot. The species of Saccocoelioides have been reported in fishes from different regions of North, Middle, and South America (CURRAN et al., 2018).

In Argentina, Saccocoelioides octavus Szidat, 1970 was described from specimens collected in Astyanax fasciatus (Cuvier, 1819) (SzIDAT, 1970). Latter, LuNASCHI (2002) redescribed the species of $S$. octavus and examined specimens of Saccocoelioides bacilliformis Szidat, 1973 available and deposited in the "Colección Nacional de Parasitología, Museo Argentino de Ciencias Naturales Bernardino Rivadavia"
(MACN-Pa), Buenos Aires, Argentina. The author considered $S$. bacilliformis to be a synonym of $S$. octavus, a proposal followed by CURRAN et al. (2018) after paratypes examination of $S$. octavus deposited in the MACN-Pa.

The Lake Guaíba contributes to the formation of the Guaíba basin, and constitutes the biggest lacustrine complex in South America (NoRONHA, 1998; MENEGAT \& KIRCHHEIM, 2006). In the lake, four species of Astyanax Baird \& Girard, 1854 have been reported: Astyanax eigenmanniorum (Cope, 1894), Astyanax aff. fasciatus (Cuvier, 1819), Astyanax henseli Melo \& Buckup, 2006, and Astyanax lacustris (Lütken, 1875) (LuCENA et al., 2013; 2017). Their helminth fauna is still very poorly known and considering the trematodes, only three species of digenetic trematodes (Dendrorchis retrobiloba Volonterio \& Ponce de Léon, 2005, Genarchella parva Travassos, Artigas \& Pereira, 1928 and Zonocotyle bicaecata Travassos, 1948) have been reported in $A$. aff. fasciatus (Fortes \& HofFmanN, 1995; Gallas \& Utz, 2019). After the examination of the specimens of Saccocoelioides found in different species of Astyanax, we propose the revalidation 
of S. bacilliformis due the shape of body, position of caecal bifurcation, uterus and vitellarium. In addition, records of new hosts and a new locality are also provided.

\section{MATERIAL AND METHODS}

Between 2017 and 2018, a total of 96 specimens belonging to the species of A. eigenmanniorum $(\mathrm{n}=20), A$. aff. fasciatus $(\mathrm{n}=46)$, A. henseli $(\mathrm{n}=5)$ and A. lacustris $(\mathrm{n}=$ 25) were collected with seine nets or fyke nets by fishermen in Pintada Island $\left(30^{\circ} 17^{\prime} 11^{\prime \prime} \mathrm{S}, 51^{\circ} 18^{\prime} 01^{\prime} \mathrm{W}\right)$, Lake Guaíba, Porto Alegre city, state of Rio Grande do Sul, Brazil. Fishes were transported in ice coolers and frozen until necropsy in laboratory. The digenetic trematodes found were fixed in A.F.A. $\left(70^{\circ}\right.$ GL ethanol - 93 parts; formalin $37 \%$ - five parts; glacial acetic acid - two parts) for 48 hours and then stored in $70^{\circ} \mathrm{GL}$ ethanol (Амато \& AMATO, 2010). Helminths were stained with Delafield's hematoxylin, clarified in cedarwood oil and mounted using Canada balsam (Амато \& Амато, 2010; GaLlas \& UtZ, 2019).

In the description, terms as forebody and hindbody were used according to YAMAGUTI (1971). Measurements were made using an ocular micrometer and appear in the text in micrometers $(\mu \mathrm{m})$ unless otherwise indicated, representing the range followed between parenthesis by the mean, the standard deviation, and the sample size. Systematics used for the parasite follows Overstreet \& CURRAN (2005). Line drawings were made with light microscope. Terms as prevalence, mean intensity and mean abundance of infections follow BusH et al. (1997). Voucher specimens were deposited in the Helminthological Collection of the Instituto Oswaldo Cruz (CHIOC), Rio de Janeiro, state of Rio de Janeiro, Brazil, and in the Helminthological Collection of the Natural Sciences Museum (Coleção Helmintológica do Museu de Ciências Naturais, CHMU) at the Universidade Luterana do Brasil in Canoas, Rio Grande do Sul, Brazil.

\section{RESULTS}

\section{Saccocoelioides bacilliformis Szidat, 1973 \\ (Figs 1,2)}

Redescription. Haploporidae, Chalcinotrematinae.

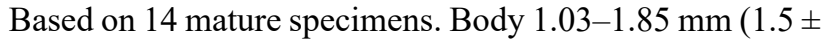
$0.3 \mathrm{~mm} ; \mathrm{n}=13)$ long, $0.24-0.45 \mathrm{~mm}(0.37 \pm 0.07 \mathrm{~mm} ; \mathrm{n}=$ 13) wide. Tegument spinose and delicate. Pigmented eyespots scattered in the region of pharynx and hermaphroditic sac. Oral sucker 100-120 (106 \pm 6$)$ long, $110-150(121 \pm 10)$ wide. Ventral sucker 90-110 $(94 \pm 6)$ long, $90-110(96 \pm 6)$ wide, distant 300-500 (344 \pm 56$)$ from anterior extremity. Ratio of total body length/oral sucker 1:14.1; ratio of oral sucker/ventral sucker 1:1.13. Prepharynx 20-120 (44 \pm 29$)$ long, 10-20 $(12 \pm 4 ; \mathrm{n}=13)$ wide. Pharynx 50-70 (58 \pm 7$)$ long, 40-70 (53 \pm 9$)$ wide. Esophagus 130-290 (204 \pm 56 ; $\mathrm{n}=11$ ) long, caecal bifurcation at the level of posterior limit or behind the ventral sucker, distant 320-560 $(411 \pm 65 ; \mathrm{n}=$ 12) from anterior extremity; intestinal caeca sacculate, short, ending about next to the ovary or between ovary and testis.
One single testis, oval to rounded, 107-250 $(159 \pm$ $43 ; n=13)$ long, $80-170(120 \pm 26 ; n=13)$ wide, next to the middle of the hindbody. External seminal vesicle longer than internal seminal vesicle. Hermaphroditic sac 105-220 (155 \pm $38 ; \mathrm{n}=13)$ long, $45-80(58 \pm 10 ; \mathrm{n}=13)$ wide, containing internal seminal vesicle, pars prostatic and the final portion of the metraterm, forming the hermaphroditic duct. Genital pore anterior to the ventral sucker, distant 240-430 (308 \pm 49) from anterior end. Ovary rounded, usually intercaecal, but always pretesticular, 70-125 (91 \pm 17$)$ long, 47-120 (73 \pm 18) wide. Laurer's canal not observed, Mehlis'gland not observed. Uterus long, inter and extracaecal, occupying all of the hindbody and reaching the ventral sucker. Numerous

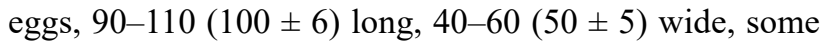
of them with developed miracidium, containing pigmented eyespot. Vitellarium constituted by generally spherical

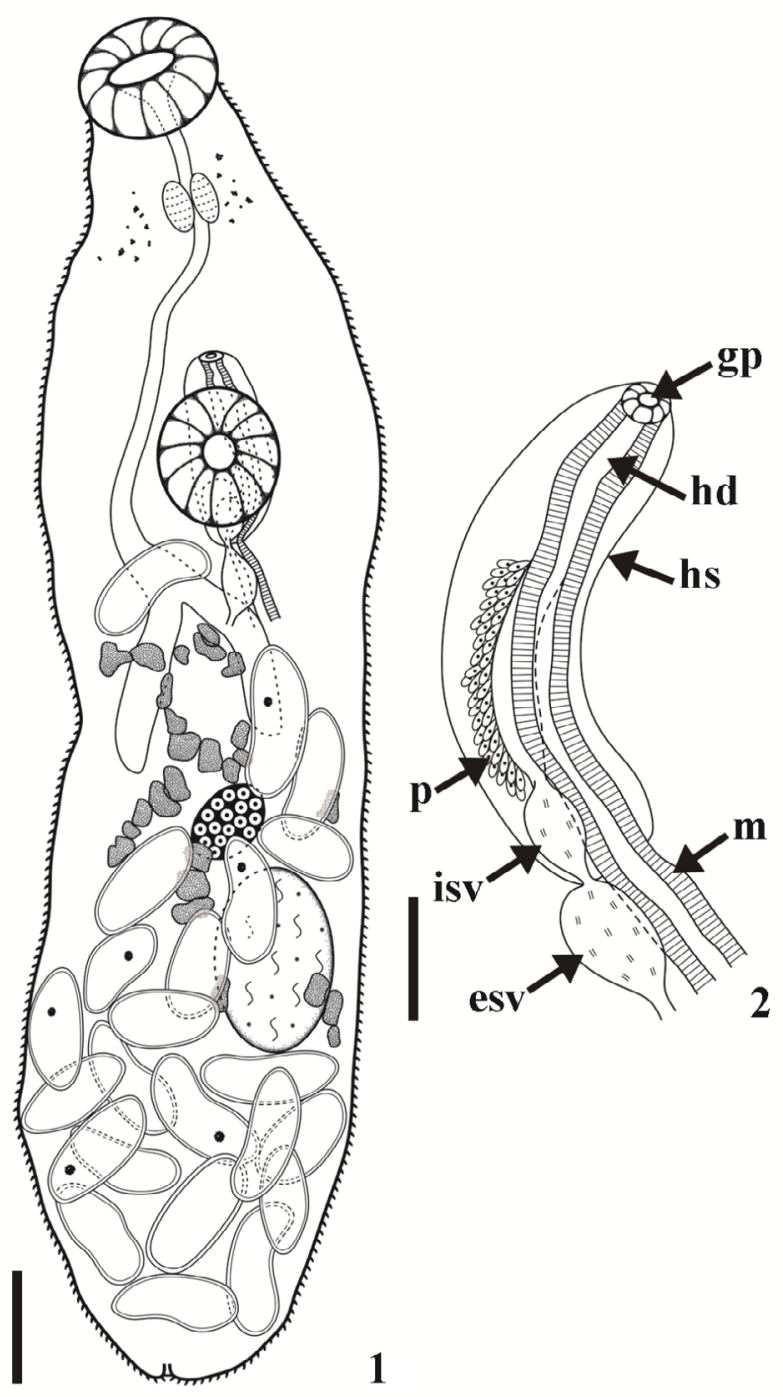

Figs 1, 2. Incomplete diagrams of Saccocoelioides bacilliformis Szidat, 1973: 1, composite, ventral view of a specimen in toto. Scale bar $=100$ $\mu \mathrm{m} ; 2$, detail of the final portion of the reproductive system (gp, genital pore; hd, hermaphroditic duct; hs, hermaphroditic sac; m, metraterm; p, pars prostatic; isv, internal seminal vesicle; esv, external seminal vesicle). Scale bar $=40 \mu \mathrm{m}$. 
follicles, ranging from the ventral sucker to the posterior limit of the testis, where in some specimens they are divided in two groups: most of them are pretesticular and a few follicles are pos-testicular. Excretory vesicle not observed, excretory pore terminal, in the posterior extremity.

\section{Taxonomic summary}

Hosts: Astyanax aff. fasciatus (Cuvier, 1819) and Astyanax henseli Melo \& Buckup, 2006 - new hosts records.

Locality: Lake Guaíba, city of Porto Alegre, state of Rio Grande do Sul, Brazil - new locality record.

Site of infection: stomach.

Prevalences: $8.7 \%$ (A. aff. fasciatus) and $40 \%$ (A. henseli). Mean intensity of infections: 15.75 helminths/host ( $A$. aff. fasciatus) and 2 helminths/host (A. henseli).

Mean abundance of infections: 1.37 helminths/host ( $A$. aff. fasciatus) and 0.8 helminth/host (A. henseli).

Amplitude of the intensity of infections: 1 to 54 helminths in $A$. aff. fasciatus and 1 to 3 helminths in $A$. henseli.

Voucher specimens of helminths deposited: CHIOC 40094; CHMU 291-1-1.

\section{DISCUSSION}

When redescribed S. octavus, LUNASchI (2002) compared the species with specimens of $S$. bacilliformis and considered that the latter was described based on specimens too compressed. Thus, the compared measurements of the specimens of $S$. octavus and $S$. bacilliformis were similar, leading the author to consider them identical, resulting in the synonymy of S. bacilliformis. This propose was based only on five and eight specimens of S. octavus and S. bacilliformis, respectively, from the material of SzIDAT $(1970,1973)$ deposited in the MACN-Pa. The two species present oral and ventral sucker with similar sizes or, the oral is slightly higher than the ventral sucker (SzIDAT, 1970, 1973; LUNASCHI, 2002). However, the examination of specimens found in the present study revealed substantial differences that support to consider them distinct species.

The specimens found in the present study and the specimens identified as S. bacilliformis by SzIDAT (1973), later studied by LUNASCHI (2002) present a more slender body, with practically the same width. However, the specimens identified as S. octavus and illustrated by SzIDAT (1970), LUNASCHI (2002) and CURRAN et al. (2018) present greater width in the equatorial region of the body, forming a typically fusiform body. This trait was also observed and described by LUNASCHI (2002).

In the examined specimens and those identified as $S$. bacilliformis by SZIDAT (1973) and LUNASCHI (2002), the caecal bifurcation is in the equatorial region or below to the ventral sucker. This position is different when compared with the specimens of $S$. octavus illustrated by SzIDAT (1970), LUNASCHI (2002) and CURRAN et al. (2018), where the caecal bifurcation is above the equatorial region, or above the anterior limit of the ventral sucker. This difference was also found in the specimens examined by LUNASCHI (2002).
In the specimens identified as $S$. bacilliformis the uterus always extends to the posterior end of the body (SzIDAT, 1973; Lunaschi, 2002), which is different in specimens of $S$. octavus. The uterus in $S$. octavus seems to range, in most specimens, from the ventral sucker to the posterior end of the testis (SzIDAT, 1970; LUNASCHI, 2002; CURRAn et al. 2018) and to the posterior end of the body. This character was observed in only one drawing provided by SZIDAT (1970). In the drawings provided by LUNASCHI (2002), and CURRAN et al. (2018) the uterus of the observed specimens does not extend to the posterior end, which may suggest that the specimen observed by SzIDAT (1970) is not available anymore.

The vitellaria follicles range in the two species from the ventral sucker to the posterior limit of the testis (SzIDAT, 1970, 1973; LuNASCHI, 2002) to close or in the posterior end of the body (LUNASCHI, 2002; CURRAN et al., 2018). In addition, in the specimens of $S$. octavus observed by SzIDAT (1970), the vitellaria follicles were located at both sides of the ovary. The vitellaria follicles are drop-shaped and distributed in both sides of second and third quarters of the body in $S$. bacilliformis (SzIDAT, 1973). In the species redescription, LUNASCHI (2002) described specimens of $S$. octavus and $S$. bacilliformis presenting two lateral pretesticular and a median post-testicular distribution. In the present study, the specimens presented a vitellarium distribution similar to those specimens described by SzIDAT (1973), but not usually in two groups as described by LUNASCHI (2002). In most of the specimens of $S$. octavus, the vitellarium reaches the posterior end, while in S. bacilliformis, eggs are always filling the posterior end of the body.

In general, the measurements obtained from specimens analyzed here were similar to those found by SzIDAT (1973) and LunASCHI (2002). However, the specimens of $S$. bacilliformis examined present a testis smaller (107-250 [159] long by $80-170$ [120] wide) when compared to the specimens measured by SzIDAT (1973) (250 long by 150 wide). In addition, the ventral sucker of the specimens examined here is smaller (90-110 [90]) than the specimens measured by SZIDAT (1973) (120) and LuNASCHI (2002) (103-140 [126]). The hermaphroditic sac of the individuals measured in the present study (105-220 [155] long by $45-80$ [58] wide) is also smaller than the specimens (172-262 [223] long by 69-112 [94] wide) examined by LuNASCHI (2002). These measurements suggest that specimens of $S$. bacilliformis presents morphological variation, which could be due to procedures of preparation, or a lack of previous observation.

The eggs measured in the specimens found in this work are in the range reported by SzIDAT (1973) and LUNASCHI (2002). Eggs with a developed miracidium with eyespot were observed in the specimens from this study, in the individuals examined by SzIDAT (1973) and LuNASCHI (2002), and in the specimens previously identified as $S$. bacilliformis. The presence of miracidium developed with eyespot seems to be a trait that must be checked in the specimens of $S$. octavus, given the different descriptions (SZIDAT, 1970; LUNASCHI, 2002; CURRAN et al., 2018). 
In view of these different considerations, the two species can be distinguished based on the following traits: $S$. octavus presents a fusiform body while $S$. bacilliformis presents body with only the anterior end more tapered. Saccocoelioides octavus has caecal bifurcation above or in the middle of the ventral sucker, while in S. bacilliformis the caecal bifurcation is in the middle or below the ventral sucker. In specimens of $S$. octavus the uterus does not reach the posterior end, while in S. bacilliformis it does. Vitellaria follicles in S. octavus reach the posterior end of the body, while in S. bacilliformis this part of the body is occupied by the uterus. The vitellaria follicles in S. bacilliformis is located right below the middle of the body. The measurements of the two species are similar (LuNASCHI, 2002), except those for body's length and hermaphroditic sac's length and width, thus no substantial differences were found to allow the differentiation of $S$. bacilliformis and S. octavus based on the measurements.

The specimens of $S$. bacilliformis were found in the pyloric caeca and the anterior portion of the intestine of Astyanax bimaculatus (Linnaeus, 1758), previously identified as Astyanax bipunctatus (SZIDAT, 1973; LUNASCHI, 2002). In the present study the specimens were collected from the stomach of the examined hosts, maybe as result of a migration after host death. In addition, the specimens found here presented a delicate tegument, making the preparation sometimes difficult and impairing their staining and mounting (OverstreEt \& CURRAN, 2005; AguirreMACEDO \& ViolANTE-GonZÁLEZ, 2008). This feature cannot be avoided due the methodology of fish sampling for posterior examination in laboratory.

The intensity of infection found in the present study was higher in $A$. aff. fasciatus (15.75 helminths/host) than in $A$. henseli ( 2 helminths/host). There is no data about the parameters of infections such as prevalence, intensity or abundance of infections for $S$. bacilliformis. In the life cycle of $S$. octavus, the fish becomes infected after the ingestion of encysted metacercariae as previously reported by SzIDAT (1970). It is possible that the reason of high intensity of infection in $A$. aff. fasciatus is the ingestion of random material in comparison with $A$. henseli. This non-selective feeding habit may increase the possibility of $A$. aff. fasciatus to become infected by $S$. bacilliformis.

KoHN et al. (2007) listed 15 valid species of Saccocoelioides from South America: Saccocoelioides antonioi Lunaschi, 1984, S. bacilliformis, Saccocoelioides carolae Lunaschi, 1984, Saccocoelioides elongatus Szidat, 1954, Saccocoelioides godoyi Kohn \& Fróes, 1986 (= Saccocoelioides szidati (Szidat, 1954) Travassos, Freitas \& Kohn, 1969), Saccocoelioides magniovatus Szidat, 1954, Saccocoelioides magnorchis Thatcher, 1978, Saccocoelioides magnus Szidat, 1954, Saccocoelioides nanii Szidat, 1954 (type species), S. octavus, Saccocoelioides quintus Thatcher, 1978, Saccocoelioides rotundus Thatcher \& Jégu, 1996, Saccocoelioides saccodontis Thatcher, 1978 and Saccocoelioides tarpazensis Diaz \& Gonzáles, 1990, but eight (S. elongatus, S. godoyi, S. magniovatus, S. magnorchis,
S. magnus, S. nanii, S. rotundus and $S$. saccodontis) were reported in Brazil (Guidelli et al., 2006; KoHN et al., 2007; ТАКемото et al., 2009; AzEvedo et al., 2010). However, the validity of some species of Saccocoelioides has been discussed by some authors (CURRAN et al., 2018; ANDRADEGómEZ et al., 2019).

Until now, only Saccocoelioides nanii Szidat, 1954 and S. szidati (reported as S. godoyi) were found in Leporinus elongatus Valenciennes, 1850 (= Megaloporinus obtusidens Valenciennes, 1837) and M. obtusidens from Lake Guaíba (KoHn \& FróEs, 1986; ForTes \& HofFMANN, 1995; WendT et al., 2018). This is the first report of $S$. bacilliformis in $A$. aff. fasciatus and $A$. henseli from Lake Guaíba, contributing to the knowledge of their helminth fauna and to the biodiversity of digenetic trematodes in fish from Brazil. Moreover, additional observations on the morphology of $S$. bacilliformis and $S$. octavus were provided in order to distinguish both species.

Acknowledgements. We thank the fishermen for host collection; MG thanks the Conselho Nacional de Desenvolvimento Cientifico e Tecnológico (CNPq) for financial support (process number 140639/2016-0).

\section{REFERENCES}

Aguirre-Macedo, M. L. \& Violante-GonzÁlez, J. 2008. Saccocoelioides lamothei n. sp. from Dormitator latifrons (Pisces: Eleotridae) from coastal lagoons of Guerrero, Mexico. Revista Mexicana de Biodiversidad 79(suppl.):33-40.

Амато, J. F. R. \& Амато, S. B. 2010. Técnicas gerais para coleta e preparação de helmintos endoparasitos de aves. In: Von Matter, S.; Straube, F. C.; Accordi, I. A.; Piacentini, V. Q. \& CÂndido-JR, J. F. orgs., Ornitologia e Conservação: Ciência Aplicada, Técnicas de Pesquisa e Levantamento. Rio de Janeiro, Technical Books, p. 369-393.

Andrade-Gómez, L.; Sereno-Uribe, A. L. \& García-Varela, M. 2019. Description of a new species and understanding the genetic diversity of Saccocoelioides Szidat, 1954 (Haploporidae) in Middle America using mitochondrial and nuclear DNA sequences. Parasitology International 71:87-98.

Azevedo, R. K.; Abdallah, V. D. \& Luque, J. L. 2010. Acanthocephala, Annelida, Arthropoda, Myxozoa, Nematoda and Platyhelminthes parasites of fishes from the Guandu river, Rio de Janeiro, Brazil. Chek List 6(4):659-667.

Bush, A. O.; Lafferty, K. D.; Lotz, J. M. \& Shostak, A. W. 1997. Parasitology meets ecology on its own terms: Margolis et al. revisited. Journal of Parasitology 83(4):575-583.

Curran, S. S.; Pulis, E. E.; Andres, M. J. \& Overstreet, R. M. 2018. Two new species of Saccocoelioides (Digenea: Haploporidae) with phylogenetic analysis of the family, including species of Saccocoelioides from North, Middle, and South America. Journal of Parasitology 104(3):221-239.

Fortes, E. \& HoffMAnN, R. P. 1995. Levantamento da fauna parasitária de peixes do Lago Guaíba, Porto Alegre, Rio Grande do Sul, Brasil. Revista Brasileira de Medicina Veterinária 17(3):107-111.

Gallas, M. \& Utz, L. R. P. 2019. First report of Dendrorchis retrobiloba Volonterio \& Ponce de León, 2005 (Digenea, Gorgoderidae) in Astyanax aff. fasciatus (Cuvier, 1819) (Characiformes, Characidae) from southern Brazil. CheckList 15(3):1-5.

Guidelli, G.; Tavechio, W. L. G.; Takemoto, R. M. \& Pavanelli, G. C. 2006. Fauna parasitária de Leporinus lacustris e Leporinus friderici (Characiformes, Anostomidae) da planície de inundação do alto rio Paraná, Brasil. Acta Scientiarum, Biological Sciences 28(3):281-290.

Kohn, A.; Fernandes, B. M. M. \& Cohen, S. C. 2007. South American Trematodes Parasites of Fishes. Rio de Janeiro, Imprinta Express. $318 \mathrm{p}$.

Kohn, A. \& Fróes, O. M. 1986. Saccocoelioides godoyi n. sp. (Haploporidae) and other trematodes parasites of fishes from the 
Guaiba estuary, RS, Brazil. Memórias do Instituto Oswaldo Cruz 81(1):67-72.

Lucena, C. A. S.; Castro, J. B. \& Bertaco, V. A. 2013. Three new species of Astyanax from drainagens of southern Brazil (Characiformes: Characidae). Neotropical Ichthyology 11(3):537-552.

Lucena, C. A. S.; Zaluski, A. B. \& Lucena, Z. M. S. 2017. Astyanax taurorum a new species from dos Touros River, Pelotas River drainage, an upland southern Brazilian river (Characiformes: Characidae). Zoologia 34:e20174.

LuNASCHI, L. I. 2002. Redescripcion de Saccocoelioides octavus Szidat, 1970 y S. bacilliformis Szidat, 1973 (Digenea, Haploporidae), parasitos de peces del genero Astyanax Baird \& Girard 1854 (Pisces: Characidae). Gayana 66(1):31-37.

Menegat, R. \& Kirchieim, R. E. 2006. Lagos, rios e arroios: as doces águas da superfície. In: Menegat, R.; Porto, M. L.; Carraro, C. C. \& Fernandes, L. A. D. eds. Atlas ambiental de Porto Alegre. Porto Alegre, Editora da UFRGS, p. 35-42.

Noronha, L. C. ed. 1998. Baía de todas as águas: preservação e gerenciamento ambiental na Bacia Hidrográfica do Guaíba. Porto Alegre, Secretaria da Coordenação e Planejamento do Estado do Rio Grande do Sul. 112p.

Overstreet, R. M. \& Curran, S. S. 2005. Family Haploporidae Nicoll, 1914. In: Jones, A.; Bray, R. A. \& Gibson, D. I. eds. Keys to the Trematoda. Volume 2. Wallingford, CABI Publishing, p. 129-165.
SzIDAT, L. 1954. Trematodes nuevos de peces de agua dulce de la República Argentina y un intento para aclarar su carácter marino. Revista del Instituto Nacional de Investigación de las Ciencias Naturales y Museo Argentino de Ciencias Naturales Bernardino Rivadavia. Ciencias Zoológicas 3(1):1-85.

SzIDAT, L. 1970. Saccocoelioides octavus n. sp., una nueva especie del genero Saccocoelioides Szidat 1954. Revista del Museo Argentino de Ciencias Naturales Bernardino Rivadavia 10(5):87-100.

SzIDAT, L. 1973. Sobre una nueva especie del genero Saccocoelioides Szidat 1954 de Astyanax bipunctatus, Saccocoelioides bacilliformis sp. nov., del Rio Reconquista, Provincia de Buenos Aires. Comunicaciones del Museo Argentino de Ciencias Naturales Bernardino Rivadavia y Instituto Nacional de Investigación de las Ciencias Naturales. Parasitología 1(7):97-100.

Takemoto, R. M.; Pavanelli, G. C.; Lizama, M. A. P.; Lacerda, A. C. F.; Yamada, F. H.; Moreira, L. H. A.; Ceschini, T. L. \& Bellay, S. 2009. Diversity of parasites of fish from the Upper Paraná River floodplain, Brazil. Brazilian Journal of Biology 69(2, suppl.):691-705.

Wendt, E. W.; Monteiro, C. M. \& Amato, S. B. 2018. Helminth fauna of Megaleporinus obtusidens (Characiformes: Anostomidae) from Lake Guaíba: analysis of the parasite community. Parasitology Research 117(8):2445-2456.

YAmaguti, S. 1971. Synopsis of digenetic trematodes of vertebrates. Volumes I and II. Tokyo, Keigaku Publishing. 1074p. 